\title{
Model Tatakelola Grup Rapa'i Daboh Bungong Jeumpa di Kawasan Pengungsian Pasca Tsunami Aceh, CARE
}

\section{Governance Model of the Rapa'i Daboh Bungong Jeumpa Group in the Post-Tsunami Refugee Area in Aceh, CARE}

\author{
Rika Wirandi1), Magfhirah Murni B.P.2) \& Berlian Denada1)*
}

1)Program Studi Seni Karawitan, Jurusan Seni Pertunjukan, Institut Seni Budaya Indonesia Aceh, Indonesia

2) Program Studi Seni Tari, Jurusan Seni Pertunjukan, Institut Seni Budaya Indonesia Aceh, Indonesia

3) Program Studi Seni Karawitan, Jurusan Seni Pertunjukan, Institut Seni Budaya Indonesia Aceh Indonesia

Diterima: 17 September 2020; Direview: 26 September 2020; Disetujui: 03 November 2020 *Coresponding Email rikawirandi@isbiaceh.ac.id

\section{Abstrak}

Artikel ini-bertujuan untuk mengetahui bentuk tatakelola yang diterapkan dalam Grup Rapa'i Daboh Bungong Jeumpa (GRDBJ) di kawasan pengungsian Pasca Tsunami Aceh, CARE, di Kota Jantho, Kabupaten Aceh Besar. Masalah yang difokuskan pada bentuk tatakelola GRDBJ dengan mengunaakan acuan pendekatan fungsi manajemen yang dikemukakan oleh Goerge R. Terry. Adapun fungsi manajemen terdiri dari empat: 1) Perencanaan (planning); 2) Pengorganisasian (organizing); 3) Penggerakan (actuating); dan 4) Pengawasan (controlling). Metode penelitian yang digunakan dalam penelitian ini adalah metode penelitian kualitatif sebagai prosedur penelitian yang menghasilkan data deskriptif berupa kata-kata tertulis dari orang-orang dan perilaku yang dapat diamati dengan menggunakan beberapa tahapan pengumpulan data yaitu: observasi; studi pustaka; wawancara; dan dokumentasi. Kajian ini menyimpulkan bahwa perencanaan yang dilakukan GRDBJ meliputi menyiapkan sumber daya anggota secara kualitas dan kuantitas. Pada aspek pengorganisasian, GRDBJ memiliki susunan organisasi formal yang diterapkan secara umum dalam sebuah organisasi, selain itu terdapat peran sentral dan signifikan khalifah dan ceh. Pada pergerakan, GRDBJ menerapkan efisiensi kerja melalui pemanfaatan SDM dan fasilitas secara optimal. Selain itu, GRDBJ melakukan pembinaan grup asuh yang terdiri dari anak-anak usia dini. Bentuk pengawasan meliputi pengawasan terhadap kinerja anggota atau pemain, keuangan, materi pertunjukan.

Kata Kunci: Tatakelola; Grup Rapa'i Daboh Bungong Jeumpa; CARE.

\begin{abstract}
This article aims to determine the form of governance applied in the Rapa'i Daboh Bungong Jeumpa Group (GRDBJ) in the post-Tsunami refugee area in Aceh, CARE, in Jantho City, Aceh Besar District. The problem is focused on the form of GRDBJ governance by using the management function approach reference proposed by Goerge R. Terry. The management function consists of four: 1) Planning (planning); 2) Organizing (organizing); 3) Movement (actuating); and 4) controlling. The research method used in this study is a qualitative research method as a research procedure that produces descriptive data in the form of written words from people and behavior that can be observed using several stages of data collection, namely: observation; literature review; Interview; and documentation. This study concludes that the planning carried out by GRDBJ includes preparing member resources in quality and quantity. In the organizational aspect, GRDBJ has a formal organizational structure that is generally applied in an organization, besides that there is a central and significant role for the caliph and ceh. In the movement, GRDBJ applies work efficiency through optimal utilization of human resources and facilities. In addition, GRDBJ conducts foster group coaching consisting of young children. The form of supervision includes supervision of the performance of members or players, finances, performance materials.

Keywords: Governance; Grup Rapa'i Daboh Bungong Jeumpa; CARE.

How to Cite: Wirandi, R. Permata, M.M.B. Denada, B. (2020). Model Tatakelola Grup Rapai Daboh Bungong Jeumpa di Kawasan Pemukiman Pasca Tsunami Aceh, CARE. Journal of Education, Humaniora and Social Sciences (JEHSS). 3 (2): 506-517
\end{abstract}




\section{PENDAHULUAN}

Kajian akademis tentang bentuk-bentuk kesenian yang disebut 'tradisional', entah dengan pendekatan etnomusikologi, antropologi, atau kajian garapan (performence studies), biasanya dipusatkan pada peristiwa pergelarannya, konteks sosial, sejarah, serta analisis bentuk dan gaya, tetapi langka pada seluk-beluk rinci sebagaimana pelaku pergelarannya dikelola dan melakukan swakelola (Lindsay. 2006). Apa yang dijabarkan Lindsay secara umum telah mengantarkan pemahaman kita bahwa kajian tatakelola kelompok seni masih sangat minim di tengah eksistensi, dinamika dan pasang surut kelompok-kelompok seni tradisional, termasuk kelompok musik tradisional di berbagai daerah di Indonesia.

Grup Rapa'i Daboh Bungong Jeumpa (selanjutnya disingkat GRDBJ) salah satu bentuk kelompok kesenian tradisional di Indonesia dengan sistem tatakelola yang khas. Kelompok ini yang dibentuk oleh masyarakat pengungsian pasca Tsunami Aceh dari Pulau Aceh ke Gampong Jantho, Kabupaten Aceh Besar. Grup ini dihidupkan oleh masyarakat 'pengungsian' dari berbagai desa di Pulau Aceh pasca terjadinya bencana Nasional - Tsunami Aceh, yang terjadi pada tahun 2004 lalu. Hadirnya kelompok ini dianggap sebagai bentuk generasi baru yang berperan sebagai sistem perekat sosial kelompok masyarakat pengungsian pasca bencana dari Pulau Aceh di Kota Jantho.

Dalam perjalanan GRDBJ selama berada di wilayah sosio-geografis yang berubah, kelompok ini mampu bertahan bahkan berkembang. Hal tersebut dibuktikan dengan hadirnya kelompok rapa'i anak-anak dengan nama Grup Rapa'i Daboh Bungong Jeumpa Bantimoh (GRDBJB) sebagai grup-asuh atau "cabang", yang telah terbentuk dan telah berusia dua tahun. Pola pengembangan grup-asuh oleh GRDBJ mengindakasikan kelompok tersebut mampu hidup dan bertahan di tengah sulitnya situasi politik-ekonomi yang dirasakan di wilayah pengungsian pasca bencana.

Peran syeh/ ceh sebagai pemimpin memiliki andil besar dalam keberlangsungan hidup GRDBJ. Peran tersebut yang mencakup dari segi sistem kepemilikan dan pengelolaan serta pertunjukan. Ceh dalam GRDBJ secara formal merupakan ketua kelompok yang mengurusi (hampir) segala aspek yang berkaitan dengan pengelolaan secara keseluruhan. Selain itu, ceh juga memiliki peranan penting sebagai pemimpin bagi para pemain rapai dalam konteks pertunjukan rapa'i daboh GRDBJ. "Dalam kaitannya dengan manajemen pada konteks seni pertunjukan, peran kepemimpinan sebagai faktor terpenting, terutama dalam pengambilan keputusan dan penentuan rencana usaha (Jazuli. 2014)." Oleh sebab itu, andil ceh dalam sistem pengelolaan sangat signifikan dengan menerapkan gaya kepemimpinan demokrasi dan kekeluargaan dalam GRDBJ.

Sebagai kelompok kesenian Islami yang memprioritaskan pada praktik kesenian yang berkaitan dengan nilai-nilai keagamaan serta bersifat relijius, GRDBJ di sisi lain juga berubah menjadi kelompok kesenian yang semi-komersil dalam menyikapi strategi pemasaran yang bertujuan untuk kebertahanan dan keberlangsungan hidup grup tersebut. Hal ini dibuktikan dengan strategi pertunjukan yang lebih fleksibel, dan tidak hanya hadir dalam konteks pertunjukan yang bersifat sakral semata. Dalam menopang biaya pemasukan, GRDBJ juga hadir pada panggung-panggung hiburan, seperti tampil pada acara-acara perayaan formal di lingkungan pemerintahan, iven-iven yang bersifat eksibisi maupun kompetisi kesenian yang diselengarakan oleh dinas terkait (kebudayaan). Selain itu, GRDBJ juga pernah tampil pada sebuah kegiatan kampanye politik salah satu calon legistalif di masa Pemilu beberapa waktu lalu.

Penelitian ini bertujuan untuk mengakomodasi dan mendokumentasi pengetahuan tradisional terkait bentuk dan strategi tatakelola yang diterapkan dalam kelompok GRDBJ dalam menghadapi sosio-geografis yang berubah. Berangkat dari penjabaran di atas, maka penelitian ini merumuskan dua permasalahan, yaitu: Pertama, bagaimana bentuk tatakelola GRDBJ di wilayah pengungsian Pasca Tsunami Aceh, CARE, Kota Jantho, Kabupaten Aceh Besar; Kedua, bagaimana strategi pengelolaan GRDBJ dalam menghadapi sosio-geografis yang berubah. Maka, penelitian ini mengungkap model tatakelola GRDJB, serta mendeskripsikan aspek-aspek lain 
yang melingkupi fokus kajian ini, di antaranya: bentuk pengelolaan, sistem kepemimpinan, dan sistem kepemilikan kelompok kesenian tradisional dalam GRDBJ.

Adapun penelitian terdahulu tentang kelompok rapa'i daboh di dusun CARE adalah, pertama: "Pewarisan Seni Rapa'i Dabo'ih sebagai Reproduksi Budaya di Perkampungan Bekas Evakuasi Pascatsunami Aceh". Penelitian tersebut memfokuskan pada bentuk pewarisan Grup Rapa'i Daboh Bungong Sitangkee sebagai cikal bakal Grup Rapa'i Daboh Bungong Jeumpa yang menjadi objek kajian dalam penelitian ini. Bentuk pewarisan dipandang sebagai salah satu upaya mereproduksi budaya oleh masyarakat di perkampungan evakuasi Pasca Tsunami Aceh yang dinamai sebagai dusun CARE.

Kedua, jurnal yang berjudul, “Keberadaan Rapa'i Dabo'ih Grup Bungong Sitangkee sebagai Reproduksi Budaya di Perkampungan Bekas Evakuasi Care Korban Pasca Tsunami Aceh". Artikel ini membahas bentuk kreativitas grup Bungong Sitangkee mempertunjukan Rapa'i Daboi'h sebagai upaya reproduksi budaya di perkampungan bekas pengungsian NGO (Non Goverment Organization) CARE di perkampungan Teurebeuh Kecamatan Kota Jantho Kabupaten Aceh Besar. Menurut teori yang digunakan dalam bahasan penelitian ini, bahwa, Reproduksi budaya adalah proses mempertahankan identitas budaya yang dilakukan oleh masyarakat korban pascatsunami sekaligus mempertahankan eksistensi kebudayaan asalnya. Reproduksi budaya di perkampungan bekas evakuasi CARE korban Pasca Tsunami Aceh, seperti dikatakan pakar budaya Pulo aceh yang berpindah kependudukan di CARE, penduduk CARE adalah penduduk pelaut dan petani cengkeh. Ketika mereka berpindah kependudukan berdampak perubahan budaya yang terjadi pada mereka. Mereka sekarang lebih memilih sebagai kuli bangunan dan bersawah. Begitu juga perubahan terjadi pada budaya seni mereka, pertunjukan rapa'i daboh di Pulo Aceh adalah sebuah kompetisi dan di CARE hanya sebuah hiburan dan tontonan semata serta mereka lebih mengikuti pasar atau konsumen (Andika \& Dilasari. 2019).

Ketiga, artikel ilmiah yang berjudul "Manajemen Grup Sendratari pada program Studi Sendratasik Universitas Palangka Raya (UPR)" dalam jurnal Tata Kelola Seni, oleh Elvira (2019). Tulisan ilmiah ini membahas tentang proses pengelolaan manajemen kegiatan Grup Sendratari Tambu Bungai Gaib Melambun Prodi Sendratasik Universitas Palangka Raya dengan menggunakan pendekatan kualitatif. Penelitian ini mengungkapkan bahwa grup Sendratari Prodi Sendratasik Universitas Palangka Raya ini memiliki manajemen kekeluargaan karena berada di lingkungan komunitas Unit Kegiatan Mahasiswa dengan tanggung jawab di bawah pimpinan dan dosen program studi bidang seni drama, tari, dan musik. Kemudian juga dijelaskan bahwa peran mahasiswa sebagai wadah terbentuknya susunan organisasi grup sendratari yang dikelola langsung oleh mahasiswa. Selain itu, penelitian ini mengungkapkan bahwa, ada empat fungsi manajemen yang diterapkan pada grup tersebut, di antaranya, perencanaan (planing); pengorganisasian (organizing); pergerakan (actuating); dan pengawasan (controlling).

Keempat, artikel ilmiah yang berjudul "Strategi Pengelolaan Sanggar Seni Sidoum di Kota Langsa, Aceh" dalam jurnal Tata Kelola Seni”. Kajian difokuskan pada mengungkap strategi yang perlu diterapkan oleh pengelola dalam rangka menjaga eksistensi sanggar di tengah persaingan global, dan mengakaji bentuk rancangan penerapan strategi pada Sanggar Seni Sidoum. Penelitian ini menggunakan pendekatan penelitian kualitatif. Analisis data menggunakan metode SWOT. Penelitian ini menunjukkan bahwa Sanggar Seni Sidoum perlu melakukan pemilihan strategiberupa penggunaan setiap kekuatan (strenght) untuk menghadapi segala ancaman (threat) dengan melakukan penetrasi pasar, pengembangan pasar, pengembangan produk, dan ofensif yang menggunakan strategi mempertahankan dan memelihara, sehingga sanggar tersebut dapat dikelola dengan baik dan mewujudkan manusia yang berbudaya, mandiri, serta menjadi pusat informasi dan menjadi wadah komunikasi para seniman untuk perkembangan seni dan budaya.

\section{METODE PENELITIAN}

Metode penelitian pada umumnya terbagi kepada dua metode yang lazim digunakan yaitu metode penelitian kualitatif dan metode penelitian kuantitatif. Dari dua jenis metode penelitian ini nantinya menggunakan metode penelitian kualitatif. "Penelitian kualitatif didefinisikan oleh 
Bogdan dan Taylor sebagai prosedur yang menghasilkan data deskriptif berupa kata-kata tertulis atau lisan dari orang-orang dan perilaku yang dapat diamati (Bogdan dan Taylor dalam Moleong, 2017). Untuk mendukung metode penelitian kualitatif sebagai metode penelitian yang telah dipilih, maka juga dilakukan beberapa tahapan penelitian. Adapun beberapa tahapan sesuai dengan dikemukakan oleh Bogdan. Ia menyajikan tiga tahapan dalam melakukan proses penelitian kualitatif, yaitu: (1). Pralapangan; (2). Kegiatan lapangan; (3). Dan analisis intensif (Bogdan dan Taylor dalam Moleong. 2017). Untuk itu, dalam proses penelitian ini telah dilakukan beberapa langkah sebagai bagian dari beberapa tahap penelitian sesuai dengan yang dinyatakan Bogdan.

Tahap pra lapangan ini berbentuk studi pustaka yang menjadi langkah awal dalam melakukan suatu penelitian pada tahap ini. Studi pustaka sangat berguna untuk mengetahui apakah objek serta permasalahan yang akan diteliti ini sebelumnya sudah diteliti sebelumnya. Tahapan ini akan diawali dengan mengumpulkan referensi-referensi berupa buku, majalah, jurnal dan sumber tertulis lainnya guna memperkuat penelitian tersebut yang nantinya akan dituangkan ke dalam bentuk tulisan. Di samping itu juga menjadi pedoman dan pendukung dalam melaksanakan penelitian "Model Tatakelola Seni Grup Rapa'i Daboh Bungong Jeumpa di Kawasan Pengungsian Pasca Tsunami Aceh, CARE".

Langkah selanjutnya adalah tahap kerja lapangan untuk mengumpulan data yang akan dianalisis menjadi sebuah bentuk laporan. Dengan melakukan studi lapangan yaitu pengumpulan data-data dengan cara melakukan observasi, wawancara serta pendokumentasian yang mengunakan alat dokumentasi seperti kamera foto, kamera vidio dan alat perekam berupa handphone. Kerja lapanga dilakukan di lokasi penelitian langusng, yaitu: di dusun CARE, Gampong Teureubeh, Kota Jantho, Kabupaten Aceh Besar.

Dalam tahap kerja lapangan atau diistilahkan dengan studi lapangan ini ditempuh melalui beberapa tahap-tahap sebagai berikut:

Terkait dengan pentingnya langkah observasi (pengamatan) dalam setiap penelitian. Penulis dalam hal ini akan mengamati secara langsung aktivitas pra hingga pasca pertunjukan GRDBJ selama proses penelitian ini berlangsung nantinya. Gunanya sebagai pendukung terhadap data yang diperoleh dalam studi pustaka pada tahap pra lapangan, sekaligus untuk meminimalisir keraguan agar tidak terjadinya bias data yang diperoleh sebelum penelitian lewat studi pustaka yang dilakukan.

Proses dalam tahap ini (wawancara) akan dilakukan dalam bentuk tanya jawab antara penulis dan informan yang berkaitan langsung dengan objek yang diteliti. Narasumber yang penulis temui adalah orang-orang dari unsur pengurus atau pengelola GRDBJ serta pemain dari kelompok kesenian tersebut, dengan tujuan agar penulis mendapatkan data-data yang akurat tentang objek penelitian ini nantinya. Wawancara dilakukan bersama nasarasumber yang merupakan pelaku, penggiat, serta pengurus GRDBJ, di antaranya: Hamidan (ketua), dan Zulkifli (sekretaris).

Proses pendokumentasi sangat penting gunanya untuk membantu melengkapi data-data sebagai penunjang suatu penelitian dalam tahapan lanjutan anasis dan pengolahan data yang didapat di lapangan nantinya. Proses pendokumentasian mengunakan instrumen penelitian. Tahapan ini dilakukan dengan memanfaatkan kamera foto, kamera vidio, dan alat perekam audio berupa handphone.

Setelah mendapatkan data-data tentang objek yang akan diteliti melalui narasumber yang telah ditemui selama proses penelitian tentang model tatakelola GRDBJ di kawasan pengungsian Pasca Tsunami Aceh, CARE, di Kota Jantho, Kabupaten Aceh Besar berlangsung, maupun dari sumber-sumber lain seperti dari jurnal, laporan penelitian, buku, dan Skripsi. Selanjutnya datadata tersebut akan dipilih dan dilakukan penyisihan untuk kemudian dianalisis. Data-data yang dianalisis kemudian disusun menjadi sebuah laporan penelitian.

\section{HASIL DAN PEMBAHASAN}




\section{Kesenian Rapai Daboh di Kawasan Pemukimam Pasca Tsunami Aceh, CARE, Kota Jantho Aceh Besar}

Rapa'i daboh merupakan kesenian yang menampilkan atraksi permainan debus sebagaimana yang dikenal umumnya di beberapa daerah di Indonesia. Di aceh, kesenian rapa'i daboh tersebar di beberapa kabupaten dan kota. Kesenian akrobatis ini sering dikaitkan dengan ajaran Tarekat Rifa'iyah yang pernah tersebar di beberapa daerah di Nusantara. Hal ini juga sejalan dengan yang pernah ditulis oleh Lane, yang menyebutkan bahwa, "di antara pertunjukanpertunjukan yang dibungkus dalam seremonial Rifa'i, dan sebagian didasarkan pada histeria dan mesmerisme, dan sebagian lagi pada permainan sulap, menyakiti diri sendiri secara sadar menempati porsi yang paling banyak (Lane dan Hurgronje. 2020)." Selanjutnya, Hurgronje menambahkan, bahwa: "pertunjukan-pertunjukan ini (meskipun pada tingkat yang terus berkurang dibanding sebelumnya) secara universal dipraktikkan seluruh Kepulauan Timur di bawah nama dabus, debus atau pertunjukan gedebus. Istilah ini berasal dari bahasa Arab dabbus, jarum besi, yang digunakan sebagai instrumen utama untuk melukai badan. Orang Aceh juga berbicara menegenai daboh (senjata) dan meudaboh (penggunaan senjata) atau lain menyebutkan pertunjukan rapa'i (dari Rifa'i) istilah yang digunakan untuk menunjukkan tamborin yang digunakan dalam pertunjukan ini dan dalam zikir-zikir lain (Hurgronje. 2020)."

Di Aceh, daboih digunakan, selain juga sejata yang secara khusus terkait dengan pertunjukan ini. Tetapi, senjata yang paling lazim di negeri tersebut (rinchung, sikin dan gliwang) juga digunakan dalam pertunjukan, penampil mulai dengan melakukan beragam gerakan setengah-menari yang diselaraskan dengan waktu pembacaan, yang terus berlangsung tanpa jeda (Hurgronje. 2020)". Rapa'i daboh (rapa'i debus) merupakan pertunjukan permainan musik rapa'i yang disertai dengan atraksi debus (pertunjukan yang menghujamkan senjata tajam ke begian tubuh tertentu dari pemain debus) sebagaimana atraksi debus yang ada di daerah lainnya, seperti, Sumatera Barat dan Banten (Ediwar et.al. 2014). Grup rapa'i daboh di kawasan pemukiman Pasca Tsunami, CARE, Kabupaten Aceh Besar, dalam pertunjukannya juga menampilkan atraksi-atraksi ekstrim menggunakan berbagai senjata tajam. Sebagaimana umumnya pertunjukan debus yang diketahui, kelompok kesenian ini menyajikan pertunjukan ilmu kekebalan tubuh yang diperagakan oleh beberapa orang pemain debus yang diiringi oleh alat musik rapa'i. Permainan rapa'i dan debus dimainkan oleh belasan orang pemain yang terdiri dari laki-laki dewasa.

\section{Gambaran Umum Awal Pembentukan Grup Rapai Daboh Bungong Jeumpa di Kawasan Pemukimam Pasca Tsunami Aceh, CARE, Kota Jantho Aceh Besar}

Grup Rapa'i Daboh Bungong Jeumpa (GRDBJ) adalah kelompok rapa'i daboh yang hidup dan berkembang di kawasan pengungsian Pasca Tsunami Aceh sejak tahun 2004. Kawasan pemukiman korban Tsunami Aceh tersebut bernama Dusun CARE, di Desa Teureubeh, Kota Jantho, Kabupaten Aceh Besar. Penduduk yang mendiami kawasan pemukiman tersebut secara mayoritas berasal dari Pulau Aceh. Menurut data yang diperoleh, jumlah awal keseluruhan masyarakat Pulau Aceh yang menjadi pengungsi di kawasan pemukiman CARE sebanyak lima puluh kepala keluarga. Hingga saat ini, terdapat penyusutan angka penduduk yang mendiami kawasan pemukiman CARE dikarenakan sebagian masyarakat telah kembali ke Pulau Aceh.

GRDBJ awalnya terbentuk sekitar tahun 2005 atas bantuan dana rahabilitasi dari sebuah Lembaga Swadaya Masyarakat (LSM) bernama PKPA. LSM ini memberi bantuan untuk pemberdayaan khusus anak korban tsunami sebagai bentuk trauma healing. Reza Idria dalam artikelnya menyebutkan, bahwa, pada masa rehabilitasi dan rekonstruksi Aceh (setelah tsunami), beratus-ratus lomba seni dibuat, dari lomba menulis, membaca puisi, festival teater, musik hingga lomba berhikayat untuk merayakan perdamaian. Meski canggung karena terasing dengan bentuk-bentuk kesenian yang diperlombakan oleh NGO-NGO yang datang membantu korban bencana, gairah ingin bangkit dari keterpurukan ditunjukan masyarakat dengan turut serta mengikuti lomba-lomba tersebut. Hal ini saya kira juga berkaitan dengan begitu besarnya jumlah bantuan yang beredar di Aceh pada masa rehabilitasi pasca tsunami (Idria. 2014). 
Dana tersebut diberikan dalam bentuk bantuan peralatan berupa seperangkat alat musik tradisional rapa'i. Peralatan tersebut digunakan untuk penunjang kegiatan latihan kesenian tradisional rapa'i daboh untuk anak-anak. Pembentukan grup rapa'i daboh dengan nama Grup Rapa'i Bungong Setangkee (GRDBS) diinisiasi atas dasar permintaan masyarakat di pemukiman CARE. GRDBS inilah yang berubah nama menjadi Grup Rapa'i Daboh Bungong Jeumpa sejak tahun 2013. Perubahan nama grup sekaligus diikuti dengan perubahan struktur organiasasi kepengurusan.

Sejauh ini, faktor yang mendukung bertahannya GRDBJ selain komitmen pengurus dan masyarakat pengungsian CARE dalam menghidupkan GRDBJ, ada faktor lain yang mendukung bertahannya grup tersebut hingga saat ini, yaitu tradisi hajatan. Hajatan dapat berupa bentuk khitanan, pesta pernikahan, syukuran, dan sebagianya. Di samping keperluan hajatan, GRDBJ banyak diipertunjukan sebagai pertunjukan eksisbi untuk penyambutan tamu dalam acara pemerintahan, festival seni budaya, dan juga kampanye politik. Selain itu, konteks pertandingan kesenian tradisi yang mengakar di wilayah Aceh juga turut mendukung keberadaan keseniankesenian tradisi di Aceh, termasuk GRDBJ. Kegiatan 'tanding' kelompok kesenian tradisi tersebut biasanya dikenal oleh masyarakat Aceh dengan istilah 'betunang'.

Tradisi betunang biasanya dilakukan pada waktu-waktu dan konteks-konteks tertentu, sesuai kesepakatan masyakarat atau pelaku masing-masing kelompok kesenian. Penyelenggaran 'betunang' biasanya berhubungan dengan perayaan tradisional yan meliputi, syukuran kampung, syukuran paska panen, dan perayaan hari-hari besar Islam. Tradisi betunang biasanya melibatkan dua atau lebih kelompok kesenian. Tradisi ini juga sebagai ajang saling adu dan memamerkan ketangkasan, kamampuan, dan materi masing-masing kesenian. Penyelenggarannya memerlukan persiapan dan pembiayaan yang besar dari tuan rumah yang menyelenggarakan. Pembiayaan tradisi betunang berasal dari iyuran kolektif masyarakat.

Masyarakat Aceh memandang bahwa kesenian rapa'i juga diyakini memberikan kekuatan sosial yang dapat memberikan persatuan dan perdamaian. Dalam artian, rapa'i dalam perjalanan sejarahnya tidak hanya mengangkat moral sosial pendukungnya, tetapi juga menjadi pengikat dan pengerat jalinan sosial masyarakat (Ediwar, et.al. 2015). Bagi masyarakat dusun CARE, semangat membangun dan membina GRDBJ tidak hanya sebatas bentuk pelestarian semata maupun motif ekonomi, melainkan juga sebagai wadah untuk mengekspresikan nilai budaya yang telah menyatu dalam diri dan sosial masyarakat sejak lama.

\section{Gambaran Tata Kelola Seni Grup Rapa'i Daboh Bungong Jeumpa}

Grup Rapa'i Daboh Bungong Jeumpa (GRDBJ) adalah sebuah kelompok kesenian yang hidup dan berkembang di tengah kawasan pengungsian Pasca Tsunami Aceh, CARE, di Kota Jantho, Kabupaten Aceh Besar. Sebagai sebuah kelompok seni tradisional yang bernuansa Islami dengan klasifikasi seni akrobatik yang mempertontonkan kekebalan dari senjata tajam, kelompok ini memilik model tatakelola yang khas, khususnya dalam hal menghadapi situasi ekonomi yang berubah akibat menghadapi perubahan sosio-geografis.

Kehadiran pertunjukan seni tidak lepas dari sebuah kelompok dan komunitas kesenian. Manajemen berfungsi untuk menjamin masukan dari berbagai sumber daya organisasi, guna menghasilkan produk yang dirancang secara tepat sehingga keinginan konsumen dapat terpenuhi (Elvira. 2019). Grup Rapa'i Daboh Bungong Jeumpa di kawasan pemukiman Pasca Tsunami pada dasarnya dikelola secara tradisional. Namun, secara kepengurusan dan bentuk organisasi, kelompok ini telah mengadopsi sistem tatakelola setengah moderen. Percampuran ini dapat dilihat dari model pengelolaan seni yang cukup khas di satu sisi. Apabila dilihat dengan menggunakan prinsip dari fungsi manajemen sebagaimana yang dijelaskan Jazuli sebelumnya, maka kita dapat melihat beberapa aspek dari fungsi manajemen diterapkan dalam pengelolaan kelompok kesenian tradisi tersebut.

Praktik Arts Management (manajemen seni) umurnya sama tua dengan seni itu sendiri. Dulu para administrator seni seperti manajer opera, pengelola museum dan galeri, penyelenggara festival kebudayaan atau dalam perspektif Indonesia: panitia festival kebudayaan 
tradisional, pemimpin kelompok seni rakyat (ketoprak, wayang kulit, sanggar tari, dll.), mendapatkan pengetahuan cara mengelola (manajemen) dari pengalaman dan hubungannya dengan para pemangku kepentingan (Dani, 2019). Pengalaman yang didapat oleh para pengelola dan pengurus GRDBJ dalam mengelola kelompok keseniaanya didapat secara tradisional dan pengetahuan terhadap sistem manajemen modern yang kemudian diterapkan secara sederhana ke dalam sistem pengelolaan GRDBJ. Pengetuhuan tersebut juga berkembang karena mempelajari dan beradaptasi dengan kondisi sosio-geografis dan sistem ekonomi yang berubah di tempat domisili yang baru, dari Pulau Aceh ke kawasan pengungsian CARE.

Organisasi seni yang ada memiliki peran penting dalam menjaga keberlangsungan hidup seni baik dalam menghadirkan kesenian dan meregenerasi calon seniman (Ardiyasa. 2015). Pengetahuan akan pengelolaan dan pengorganisasian tersebut diterapkan oleh seniman dan pengurus GRDBJ untuk membentuk dan mengurusi kesenian rapa'i daboh dengan tujuan menjaga keberlangsungan hidup kesenian milik masyarakat Pulau Aceh tersebut. Upaya meregenerasi juga dilakukan pengurus GRDBJ dengan membentuk grup asuh atau grup cabang yang merupakan grup rapa'i daboh anak-anak, dengan tujuan memperkenalkan gaya baru dari kesenian tersebut yang semulanya dilakoni dan dipertunjukkan oleh para laki-laki dewasa (orang tua).

\section{Perencanaan (Planning)}

Perkembangan lembaga-lembaga kesenian di Indonesia semakin hari semakin bertumbuh dan sangat beragam, tujuannya tidak jauh berbeda yaitu untuk mencapai suatu tujuan. Terbentuknya suatu lembaga kesenian yang tetap eksis dan berkembang, tidak berjalan begitu saja tanpa adanya suatu strategi yang sesuai dengan misi ke depan. Setiap peralihan pasti memunculkan keinginan yang berbeda dari publik (audiens), oleh sebab itu strategi yang dihadirkan juga memikirkan perbedaan-perbedaan pada setiap perencanaan kegiatan (Kaiser dalam Kartika. 2017).

Perencanaan adalah serangkaian tindakan yang dilakukan sebelum usaha dimulai hingga proses usaha masih berlangsung. Perencanaan dapat dimengerti sebagai penetapan tujuan, kebijakan prosedur, program, pembiayaan (budget), standar mutu dari organisasi. Unsur utama perencanaan adalah tujuan, kebijakan, prosedur dan program (Jazuli. 2014). Selanjutnya, Jazuli juga menyebutkan bahwa, secara mendasar - ada beberapa alternatif dalam membuat perencanaan dalam suatu kelompok, di antaranya:

(1) Kemampuan, yaitu bertolak dari sumber daya dan modal yang tersedia seperti tenaga pelaksana, materi, dan keuangan; (2) Kondisi lingkungan, yaitu keadaan alam dan masyarakat sekitarnya terutama berkaitan dengan situasi sosial, budaya dan ekonomi; (3) Kompentensi, yaitu tingkat wewenang dan tanggung jawab perlu pembagian yang jelas; (4) Kerja sama, yaitu struktur organisasi cukup mudah dilaksanakan sehingga prosedur kerja dan interaksi antara para personel bisa terwujud; (5) Program, yaitu acara kerja yang dicanangkan harus rasional, matang dan luwes (mudah menyesuaikan keadaan) baik yang menyangkut tentang standar mutu, anggaran biaya, bentuk produksi, jangka waktunya, dan sebagainya (Jazuli. 2014).

Bentuk perancanaan yang dilakukan oleh pengurus Grup Rapa'i Daboh Bungong Jeumpa dalam menjalankan kelompok kesenian dapat dilihat dari segi persiapan sumber daya manusia (SDM) - dalam hal ini keanggotaan. Unsur keanggotaan dalam GRDBJ sangat mempertimbangkan kemampuan dari masing-masing individu, terutama mengenai kemampuan dalam menguasai materi permainan rapa'i dan debus (daboh). Dalam setiap penampilan, sebagaimana yang disebutkan sebelumnya, anggota yang merupakan pemain rapa'i dan debus akan diutus sebanyak lebih kurang lima belas orang. Dua belas orang untuk pemain rapai dan tiga orang untuk pemain debus. Kelima belas pemain tersebut adalah anggota tetap dan menjadi pemain utama dalam setiap pertunjukan. Pemilihan keseluruhan pemain utama tersebut didasari olah kemampuan mereka dalam bermain (rapa'i dan debus) kemampuan dalam menguasai materi. Hal ini berkaitan dengan cukup beragamnya banyaknya materi permainan karena tergantung pada konteks acara yang menampilkan kesenian ini (Wawancara dengan Hamidan, pada tanggal 14 September 2020, di CARE). 
Posisi yang selalu tetap dalam kelompok pemai rapa'i adalah syeh/ ceh. Posisi ceh dalam kelompok kesenian rapa'i daboh pada umumnya terdiri dari satu orang, yaitu, sebagai ceh utama. Selain itu, juga terdapat satu orang pemain yang menjadi ceh kedua atau ceh bantu, adalah pemain senior di antara keseluruhan pemain. Fungsi dari ceh bantu ialah untuk membantu peranan ceh utama saat permainan, ataupun sabagai pengganti apabila ceh utama berhalangan untuk tampil. Apabila dari pemain utama yang berhalangan untuk bisa tampil, akan ada pemain cadangan yang akan mengantikan. Begitupun jika beberapa pemain dalam jumlah banyak tidak bisa ikut dalam pertunjukan, maka selalu ada yang akan menjadi pemain rapa'i penganti. Pada umumnya, kaum laki-laki anak-anak, remaja, hingga dewasa di dusun CARE biasanya memiliki kemampuan dalam memainkan rapa'i daboh, dikarenakan kemampuan ini telah mereka miliki sejak kecil melalui latihan-latihan bersama kelompok rapa'i orang tua yang sering menyelenggarakan latihan rapa'i di sebuah bale gampong atau pentas untuk latihan yang biasanya dimiliki setiap desa di Aceh (Wawancara dengan Zulkarnain, pada tanggal 14 September 2020, di Kota Jantho).

Kondisi lingkungan juga sangat dipertimbangkan oleh pengurus GRDBJ, terutama kondisi sosial, budaya dan ekonomi. Kondisi tersebut merujuk pada kondisi sosial, budaya, dan ekonomi masyarakat pendukung kesenian tersebut. Secara sosial, budaya dan ekonomi, masyarakat pendukung maupun pelaku kesenian, sebagaimana yang telah disebutkan sebelumnya, merupakan masyarakat yang telah berpindah secara geografi wilayah dari Pulau Aceh ke kawasan pengungsian CARE, di Kota Jantho Aceh Besar. Pelaku kesenian rapa'i daboh yang juga merupakan masyarakat pengusian Pasca Tsunami pada umumnya menggantungkan hidup dari hasil bertani: menggarap sawah dan kebun. Kondisi ini secara fakta, cukup menyulitkan masyarakat yang pada awalnya hidup dengan kecukupan di tempat asalnya di Pulau Aceh, yang mengandalkan hasil laut dan hutan, termasuk perkebunan sebagai mata pencaharian. Kondisi berbanding terbalik ketika telah berada di kawasan pengungsian.

Rata-rata, para pelaku kesenian rapa'i daboh yang tergabung dalam GRDJB adalah masyarakat yang sebagian besar mengantungkan hidup dari hasil pertanian dan wiraswasta. Permasalahan yang menarik di sini ialah GRDBJ hampir tidak pernah mendapat bantuan dari pemerintah ataupun dinas terkait. Sejak dibentuk tahun 2005 hingga berganti kepengurusan dari tahun 2013, belum ada bantuan maupun fasilitas penunjang kesenian yang diterima dari dinas terkait. Sumber keuangan dan pendanaan GDRJB berasal dari honor yang diterima ketika ada undangan untuk melakukan pementasan. Tidak jarang, pengurus mengunakan uang pribadi untuk membantu pembiayaan proses latihan maupun biaya produksi pra pementasan. Honor kelompok yang didapat setiap undangan pementasan juga tidak ditentukan oleh pengurus. Honor yang didapat setiap selesai melakukan pertunjukan biasanya hanya cukup untuk transportasi dan konsumsi saat pementasan (wawancara dengan Zulkifli, pada tanggal 14 September 2020, di Kota Jantho).

Tabel: Sumber Dana Grup Rapa'i Daboh Bungong Jeumpa

\begin{tabular}{|c|c|c|}
\hline No. & Jenis Kegiatan & Honor yang Diperoleh \\
\hline 1. & Iven Pemerintah (Penyambutan tamu) & \pm Rp.2000.000,- \\
\hline 2. & Festival Kesenian dan Kebudayaan & \pm Rp.2000.000,- \\
\hline 3. & Kampanye Politik & \pm Rp.2000.000,- \\
\hline 4. & Festival Musik Kampus & \pm Rp. 700.000,- \\
\hline 5. & Khitanan & \pm Rp. 700.00o,- \\
\hline 6. & Pesta Perkawinan & \pm Rp. 700.000,- \\
\hline 7. & Syukuran & \pm Rp. 700.000,- \\
\hline 8. & Perhelatan Gampong (Syukuran pasca panen) & Sukarela \\
\hline 9. & Betunang & Sukarela \\
\hline
\end{tabular}

Sumber: wawancara dengan Hamidan dan Zulkifli (2020)

\section{Pengorganisasian (Organizing)}


Pengorganisasian diartikan sebagai keseluruhan proses pengelompokan orang-orang, alat, tugas dan tanggung jawab (wewenang) sedemikian rupa sehingga tercipta suatu organisasi yang dapat digerakkan menjadi suatu kesatuan kerja sama untuk mencapai tujuan. Prinsip pengorganisasian adalah pengaturan tugas dan tanggung jawab, penempatan orang pada tempat yang tepat untuk jabatan yang tepat, dan penyediaan peralatan yang sesuai dengan tugas dan fungsinya (Jazuli. 2014). Bentuk pengorganisasian dalam Grup Rapa'i Daboh Bungong Jeumpa berupa struktur organisasi sederhana yang terdiri dari: ketua, sekretaris; bendahara; anggota; dan penasehat. Di samping struktur organisasi formal tersebut, terdapat seorang khalifah yang memiliki peranan yang khas dalam GRDBJ.

Seorang pemimpin dalam organisasi keberadaannya memang penting. Namun, sumber daya manusia (dalam hal ini anggota) sebuah organisasi juga harus memiliki modal intelektual yang dapat menunjang tujuan yang hendak dicapai (Arohmi. 2019). Ketua berperan sebagai pimpinan dalam GRDBJ. Peran ketua dalam hal ini Hamidan, tidak hanya sebatas sebagai pemimpin dalam struktur organisasi formal, tapi juga sebagai pimpinan dalam kelompok rapa'i atau sebagai syeh/ ceh. Peran pengurus lainnya, seperti sekretaris dan bendara dalam GRDBJ hampir sama dengan peran sekretaris dan bendahara pada umumnya. Bendahara sebagai pengelola keuangan grup, baik berupa biaya pemasukan maupun pengeluaran grup. Bendahara dan sekretaris GRDBJ juga berperan sabagai anggota atau pemain rapa'i daboh pada saat pertunjukan. Atau dapat dikatakan, seluruh pengurus inti organisasi GRDBJ juga berperan sebagai pemain rapa'i pada saat pertunjukan. Penasehat lebih berperan dalam sebagai orang yang dituakan yang mengarahkan maupun menyelesaikan permasahan-permasalahan internal maupun eksternal kelompok. Sedangkan peran dan fungsi khalifah lebih luas dan kompleks.

Peran dan fungsi khalifah dalam GRDJB cukup signifikan. Khalifah berperan sebagai pelindung ataupun menjadi pawang pada saat pertunjukan berlangsung. Khalifah memiliki keahlian spiritual dan supranatural yang dimilikinya dalam membentengi para pemain saat melakukan pertunjukan dari gangguan dan serangan-serangan yang bersifat ghaib dan "halus" dari pihak lain, baik lawan bertanding grup ketika diadakannya acara betunang rapa'i, maupun dari pihak maupun oknum-oknum tertentu yang secara sengaja ingin mencelakakan atau menggagalkan atraksi debus yang diperagakan GRDBJ dengan cara ghaib. Selain membentengi secara supranatural, khalifah dalam kelompok rapa'i daboh, terutama dalam GRDBJ, juga berperan sebagai "tabib" yang mengobati para anggota ataupun pemain, apabila terjadi insiden atau kecelakaaan dalam melakukan atraksi debus dalam suatu pertunjukan. Oleh karena itu, khalifah selalu diikutsertakan dalam setiap pertunjukan dalam konteks apapun, terutama yang bersifat pertandingan maupun hajatan.

Khalifah juga sebagai pemberi pertimbangan kepada GRDBJ, sebelum melakukan pementasan. Hal tersebut dimaksudkan untuk mempertimbangkan keamanan dan keselamatan pemain pada saat pertunjukan berlangsung, terutama ketika tempat pertunjukan berada di luar daerah. Selain itu, pertimbangan juga didasari oleh sering terjadinya kecelakaan dalam atraksi permainan debus menggunakan senjata tajam yang terkadang melukai bagian tubuh tertentu yang menjadi sasaran tusukan. Untuk itu, peran khalifah, selain memberi pertimbangan dalam menerima atau tidaknya undangan pertunjukan yang diperuntukkan kepada GRDJB di suatu tempat tertentu, khususnya di luar kampung CARE.

Pertunjukan rapa'i daboh, sebagaimana yang telah disebutkan sebelumnya, merupakan pertunjukan kesenian yang akrobatis yang menampilkan atraksi maupun peragaan ekstrim, dengan menggunakan benda-benda tajam yang ditusukkan ke badan pemain debus. Atraksi yang terbilang cukup berbahaya ini tentunya dilakoni oleh orang-orang yang telah terlatih dan juga dengan pertimbangan-pertimbangan yang sangat ketat. Pada saat pertunjukan debus, peran khalifah, cukup sentral, terutama dalam beberapa hal yang telah disebutkan di atas. Hurgronje dalam bukunya "Orang Aceh Jilid II" mengatakan bahwa, "pertunjukan ini (daboh) dilakukan di bawah kepemimpinan seorang khalifah yang sebenarnya, yaitu, pengganti spiritual pendiri tarekat, yang silsilah geneologis spiritualnya dihubungkan dengan Ahmad Rifa'i, dan yang mendapat lisensi (ijazah) dari gurunya untuk melakukan latihan-latihan berbahaya semacam ini (Hurgronje. 2020)." 


\section{Penggerakan (Actuating)}

Penggerakan menyangkut tindakan-tindakan yang menyebabkan suatu organisasi bisa berjalan ke arah sasaran perencanaan manajerial. Prinsip penggerakkan adalah: (1) Efisiensi, yaitu pemanfaatan sumber daya dan fasilitas yang ada secara optimal guna mencapai hasil yang maksimal; (2) Komunikasi yang lancar dan manusiawi (tenggang rasa) perlu dipertahankan dalam hubungan yang sehat antar-kelompok maupun antar-pelaku organisasi; (3) Kompensasi atau penghargaan, baik berupa uang atau gratifikasi lainnya dari pimpinan (Jazuli. 2014). Penggerakan yang dilakukan pengurus GRDBJ berbentuk usaha mengelola dan menjalankan aktivitas kelompok. Penggerakan yang dilakukan meliputi pembagian tanggungjawab kerja pada struktur organisasi, menyederhanakan struktur organisasi, penjadwalan latihan secara rutin, alternatif sumber dana.

Sumber daya manusia yang dimilkili GRDBJ dirasa cukup mempuni secara kualitas maupun kuantititas. Hal ini disebabkan, rata-rata orang laki-laki dewasa CARE mampu memainkan rapa'i dan menguasai materi pertunjukan rapa'i daboh. Kemampuan tersebut didapat dari latihanlatihan dan terlibat langsung dalam kelompok kesenian rapa'i ketika masih tinggal di Pulau Aceh. Jadi, jika ada salah seseorang atau beberapa pemain berhalangan hadir, maka akan ada penganti. Namun, dalam sistem keanggotaan, GRDBJ tetap menerapkan istilah anggota inti dan anggota cadangan. Anggota inti merupakan anggota tetap yang selalu mengikuti latihan dan pengurusan kelompok GRDBJ, sedangkan anggota cadangan adalah anggota tidak tetap, yang merupakan orang-orang di luar kelompok inti. Anggota tidak tetap biasanya berperan sebagai pemain pengganti ketika salah seorang atau beberapa orang anggota berhalangan untuk ikut dalam sebiah undangan pertujukan.

Berbeda dengan ketersediaan sumber daya manusia, fasilitas yang dimilki GRDBJ terbilamg sangat terbatas. Secara umum dapat dikatakan pas-pasan. Baik itu dari segi alat musik untuk pertunjukan, kostum pertunjukan, dan perlengakpan penunjunga lainnya. Hanya saja, kelompok ini memiliki cadangan alat musik rapa'i yang khusus untuk latihan, dan dibedakan dengan alat musik rapa'i untuk pertunjukan. Ketersedian alat musik tersebut, awalnya sumbangan dari salah satu NGO, sebagaimana yang disebutkan di awal, dan kemudian sebgiannya dibeli dari dana kas yang terkumpul dari hasil pendapatan selama memenuhi undangan pertunjukan selama GRDBJ berdiri. Keterbatasan perlangkapan lainnya, dikarenakan belum adanya bantuan nyata yang didapat dari dinas terkait. Untuk mencapai hasil yang maksimal dengan perlengkapan penunjang yang terbatas, GRDBJ selalu mengoptimalkan pemakaian dan memelihara perlengkapan tersebut secara ketat. Perlengkapan disimpan dan dipelaihara oleh pengurus dan hanya boleh digunakan ketika latihan dan pertunjukan.

Pola komunikasi yang diterapkan oleh pengurus ataupun penggelola kepada pemain bersifat terbuka dan musyawarah. Pola kepemimpinan ketua dalam kepengurusan GRDBJB bersifat demokrasi. Pola pengelolaannya dilakukan secara kolektif-partisipatif-demokratis. Maksudnya, setiap urusan apapun yang terkait dengan internal kelompok, selalu dimusyawarahkan dengan seluruh anggota maupun pengurus. Persoalan bisa meliputi, mempertimbangkan undangan pertunjukan, persiapan pertunjukan, pergantian pemain rapa'i jika ada pemain inti yang berhalangan ikut dalam pertunjukan, pembagian honor, hingga pada persoalan kesalahpahaman yang terjadi antar anggota maupun pengurus.

Pembagian honor dilakukan dengan sistem bagi rata. Honor yang didapat dari undangan pertunjukan tidak tetap. Hal ini dikarenakan, GRDBJ tidak pernah mematok tarif harga untuk sekali pertunjukannya, baik undangan pertunjukan hajatan, kenduri, maupun acara pemerintah dan festival seni budaya. Honor yang didapat terkadang hanya cukup untuk biaya operasional dan konsumsi kelompok selama persiapan hingga pasca pertunjukan. Tidak jarang, keperluan yang sifatnya sekunder, seperti konsumsi latihan dan pembelian perlengkapan penunjang, terkadang memakai uang saku pengurus. Honor yang berlebih dan bisa dibagi rata kepada masing-masing anggota sebagai intensif, biasanya didapat dari undangan pertunjukan yang diterima dari pemerintah dan festival seni budaya level kabupaten hingga provinsi. Maka, tidak 
jarang, GRDBJ juga menerima undangan acara-acara kampanye politik sebagai bentuk memperluas jangakuan pasar sekaligus promosi grup.

Untuk memperluas jangkauan dapat dilakukan dengan menggunakan strategi penetrasi pasar, yakni dengan melakukan upaya sosialisasi yang lebih gencar dan mencakup pasar yang lebih luas. Untuk dapat menjangkau pasar yang lebih luas, perlu dilakukan pengembangan produk/karya sehingga lebih menarik bagi kalangan yang lebih luas. Pengembangan karya di sini bisa lebih fleksibel dengan lebih membuka diri terhadap masuknya seni tradisi yang lebih populer untuk dikombinasikan dengan seni tradisi, tanpa menghilangkan nilai-nilai yang ada di dalamnya (Riyanto. 2018). Penetrasi pasar dalam upaya promosi dilakukan GRDBJ dengan cara memperluas konteks kehadiran mereka dalam beberapa pertunjukan, di luar konteks adat yang sudah menjadi pertunjukan yang umum bagi GRDBJ, seperti hajatan, pernikahan, dan sebagainya. Hadirnya GRDBJ dalam beberapa jenis iven-iven pemerintah, menjadi salah satu strategi promosi kelompok yang masih menerapkan sistem pengelolaan tradisional bercampur dengan pengelolaan setengah profesional, dalam artian, pertunjukan demi pertunjukan rapa'i daboh bagi pengurus maupun pemain GRDBJ sebagai sarana untuk mengekspresikan diri, bukan sandaran penghasilan dan pendapatan ekonomi yang tetap bagi GRDBJ.

Bentuk pergerakan lain yang dilakukan oleh pengurus GRDBJ adalah langkah pembinaan dan pengembangan. Bentuk konkret dari hal tersebut dengan membentuk dan membina grup asuh atau grup cabang yang diberi nama Grup Rapa'i Daboh Bunggong Jeumpa Bantimoh (GRDBJB), yang beranggotakan pemain dari kalangan anak-anak yang berusia empat hingga dua belas tahun. Selain sebagai salah satu upaya untuk pembinaan dan pengembangan dalam aspek pergelaran dan pengelolaan, tujuan dibentuknya GRDBJB oleh pengurus GRDBJ adalah bentuk usaha menampakkan kemampuan kelompok ini dalam menghadapi dan beradaptasi dengan sosio-geografis dan situasi ekonomi yang berubah di kawasan pengungsian Pasca Tsunami, CARE. Sebagaimana yang disampaikan Lindsay, bahwa, kesadaran tentang pentingnya kemampuan adaptasi dalam menghadapi situasi ekonomi yang berubah, dan dalam menanggani persaingan, sangatlah kentara. Grup-grup mengembangkan pendekatan baru dalam pergelaran dan tatakelolanya; misalnya, melalui promosi seperti seperti menawarkan diskon, menjual rekaman, atau membuka grup-asuh baru yang memperkenalkan gaya baru (Lindsay. 2006).

\section{Pengawasan (Controlling)}

Pengawasan adalah kegiatan pimpinan dalam mengupayakan agar pekerjaan sesuai dengan perencanaan yang ditetapkan dan tujuan yang telah ditentukan (Jazuli. 2014). Dalam Grup Rapa'i Daboh Bungong Jeumpa, fungsi pengawasan biasanya dilakukan oleh ketua dan pengurus inti. Pengawasan meliputi kinerja anggota atau pemain, keuangan, materi pertunjukan. Pengawasan dilakukan dalam bentuk musyawarah sebelum dan sesudah pertunjukan. Musyawarah dilakukan dalam rangka evaluasi terkait capaian terhadap pertunjukan yang dilakukan. Pengawasan juga dilakukan dalam bentuk pemantauan kegiatan latihan para anggota.

Kegiatan latihan dilakukan dua kali dalam seminggu untuk dua kelompok berberbeda: kelompok dewasa dan anak-anak. Jadwal latihan kelompok dewasa (GRDBJ) dilakukan pada malam Sabtu. Sedangkan jadwal latihan kelompok rapa'i daboh anak-anak (GRDBJB) dilakukan pada hari Minggu. Untuk jadwal tambahan biasanya dilakukan setiap ada undangan pementasan. Jadwal latihan dilakukan sebanyak tiga sampai lima kali berturut-turut sebelum pementasan. Hal tersebut bertujuan, selain untuk menghapal materi - juga bertujuan untuk menyepakati materi yang akan dibawakan dengan menyesuaikan konteks kegiatan.

Jadwal latihan tambahan dilakukan bertujuan untuk menyempurnakan materi yang akan dipertunjukan. Selain itu, untuk mempererat bangunan komunikasi antar pemain dan pengurus di luar sistem koordinasi dan komunikasi pengurus dan anggota. Intensitas latihan yang cukup rutin pra pertunjukan biasanya diawasi langsung oleh pengurus inti, termasuk penaseha dan khalifah. Hal ini bertujuan agar memberi arahan dan bimbingan untuk mengurasi risiko selama pertunjukan, dikarenakan GRDBJ adalah kelompok kesenian rapa'i daboh yang mempertunjukan ektrim dan berbahaya.

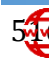




\section{SIMPULAN}

Pelaku pertunjukan rapa'i daboh yang terhimpun dalam Grup Rapa'i Daboh Bungong Jeumpa merupakan masyarakat yang mendiami kawasan pemukiman Pasca Tsunami Aceh, CARE. Dalam kondisi sosio-geografis yang berubah yang juga berdampak pada kondisi ekonomi, masyarakat tersebut mampu mendirikan kelompok kesenian dan mengelola dengan cukup baik, tanpa bantuan pendanaan dari pemerintah dan dinas terkait. Mereka secara mandiri menghidupkan GRDBJ secara kolektif dan swadaya. Dikelola dengan menerapkan perpaduan manajemen moderen dan tradisional yang khas. Hasil dari komitmen pengelolaan tersebut juga dapat dilihat dengan dibentuknya grup asuh berupa grup rapa'i daboh anak-anak sebagai generasi muda yang mewarisi tradisi yang telah hidup dan berkembang cukup lama di Aceh tersebut.

Kajian ini menyimpulkan bahwa perencanaan yang dilakukan GRDBJ meliputi menyiapkan sumber daya anggota secara kualitas dan kuantitas. Pada aspek pengorganisasian, GRDBJ memiliki susunan organisasi formal yang diterapkan secara umum dalam sebuah organisasi, selain itu terdapat peran sentral dan signifikan khalifah dan ceh. Pada pergerakan, GRDBJ menerapkan efisiensi kerja melalui pemanfaatan SDM dan fasilitas secara optimal. Selain itu, GRDBJ melakukan pembinaan grup asuh yang terdiri dari anak-anak usia dini. Bentuk pengawasan meliputi pengawasan terhadap kinerja anggota atau pemain, keuangan, materi pertunjukan.

\section{UCAPAN TERIMA KASIH}

Terima kasih peniliti beserta tim sampaikan kepada Direktorat Riset dan Pengabdian Masyarakat (DRPM), Direktorat Jenderal Penguatan Riset dan Pengembangan, sebagai pemberi dana hibah penelitian ini melalui program dana Hibah Penelitian Dosen Pemula (PDP). Terimakasih kepada Institut Seni Budaya Indonesia Aceh, LPPMPMP ISBI Aceh, Kepada Pengurus Grup Rapa'i Daboh Bungong Jeumpa dan Grup Rapa'i Daboh Bungong Bantimoh serta seluruh masyarakat dusun CARE, Gampong Teureubeh, Kota Jantho, Kabupaten Aceh Besar.

\section{DAFTAR PUSTAKA}

Andika, B. \& Dilasari, F., (2019), Keberadaan Rapa'i Dabo'ih Grup Bungong Sitangkee sebagai Reproduksi Budaya di Perkampungan Bekas Evakuasi Care Korban Pasca Tsunami Aceh, Gorga: Jurnal Seni Rupa, 08 (02): 455-459.

Arohmi, Y. S. F., (2019), Peran Modal Intelektual Sumber Daya Manusia dalam Pengelolaan Festival yang Berkelanjutan (Studi Kasus Festival Ngayogjazz), Jurnal Tata Kelola Seni, 5 (1): 19-28.

Ardiyasa, I Putu., (2015), Strategi Pengelolaan Sanggar Seni Anacaraka dalam Mewadahi Bakat Anak-Anak di Pegunungan Kintamani Bali, Jurnal Tata Kelola Seni, I (2): 31-45.

Dani, Iwan S., (2019), Perkembangan Studi Tata Kelola Seni dan Risetnya di Aras Global dan Lokal, Jurnal Tata Kelola Seni, 5 (2): 88-102.

Dilasari, F. \& Andika, B., (2019), Pewarisan Seni Rapa'i Dabo'ih sebagai Reproduksi Budaya di Perkampungan Bekas Evakuasi Pascatsunami Aceh, Jurnal Panggung, 30 (3): 425-440.

Ediwar, Soerjana, D. \& Metro, W., (2015), Rekonstruksi dan Revitalisasi Kesenian Rapa'i Aceh Pasca Tsunami, Padangpanjang: ISI Padangpanjang Press.

Elvira, (2019), "Manajemen Grup Sendratari pada Program Studi Sendratasik Universitas Palangka Raya (UPR)", Jurnal Tata Kelola Seni, 5 (2): 76-87.

Hurgronje, C. S., (2020), Orang Aceh: Ilmu Pengetahuan, Sastra, Permainan, dan Agama, Yogyakarta: Penerbit Mata Bangsa.

Idria, R., (2014), Dua Penggung Pertunjukan di Aceh: dari Konflik Negara ke Politik Syariat, Seni Pertunjukan Indonesia Pasca Orde Baru, Yogyakarta: Penerbit Universitas Sanata Darma.

Jazuli, M., (2014), Manajemen Seni Pertunjukan Edisi 2, Yogyakarta: Graha Ilmu.

Kartika, R. Y., (2017), "Strategi Pengelolaan Sanggar Seni Sidoum di Kota Langsa Aceh", Jurnal Tata Kelola Seni, 3 (2): 54-68.

Lindsay, J., (Ed.)., (2006), Telisik Tradisi: Pusparagam Pengelolaan Seni, Jakarta: Yayasan Kelola.

Moleong, Lexy J., (2017), Metodologi Penelitian Kualitatif, Bandung: PT. Remaja Rosdakarya.

Riyanto, J., (2018), Pengembangan Strategi Pengelolaan Sanggar Srengenge Mas Bantul, Jurnal Tata Kelola Seni, 4 (1): 49-62. 